\title{
Analisis Etnografi Virtual Tentang Proses Komunikasi Kesehatan Ibu dan Anak dalam Whatsapp Group "Tentang Anak"
}

\author{
${ }^{1}$ Ditha Prasanti, ${ }^{2}$ Sri Seti Indriani \\ Fakultas Ilmu Komunikasi Universitas Padjadjaran, Jl Raya Bandung-Sumedang KM 21 Jatinangor \\ E-mail: ${ }^{1}$ dithaprasanti@gmail.com, ${ }^{2}$ rahadianindri@gmail.com
}

\begin{abstract}
Abstrak. Penelitian ini berawal dari ketertarikan penulis mengenai para ibu yang sekaligus merupakan perempuan urban serta mengedepankan konsep literasi kesehatan tentang perawatan, penyembuhan, serta kondisi kesehatan anaknya, jika anaknya mengalami sakit. Tujuan penelitian ini adalah ingin mendeskripsikan tentang proses komunikasi kesehatan yang terjadi dalam whatsapp group "Tentang Anak" tersebut; topik pembicaraan yang dilakukan dalam whatsapp group "Tentang Anak" tersebut; serta hambatan komunikasi yang terjadi selama proses komunikasi kesehatan dilakukan. Penelitian ini menggunakan pendekatan kualitatif dengan metode etnografi virtual. Hasil penelitian menunjukkan bahwa proses komunikasi kesehatan yang berlangsung meliputi pencarian informasi kesehatan para ibu tersebut tentang kesehatan anaknya dalam whatsapp group "Tentang Anak". Topik pembicaraan yang dilakukan seputar informasi pola hidup sehat bagi anak, tumbuh kembang anak, perawatan anak, dan teknik penyembuhan anak apabila mengalami sakit apapun. Hambatan komunikasi yang ada dalam proses komunikasi kesehatan tersebut adalah hambatan personal, hambatan pendidikan, dan hambatan waktu.
\end{abstract}

Kata Kunci: proses komunikasi kesehatan, ibu dan anak, etnografi virtual.

\begin{abstract}
It was starting from the author's interest in mothers who are both urban women and put forward the concept of health literacy about care, healing, and health conditions of their children, if their children experience illness.. The purpose of this study is to describe the process of health communication that occurs in whatsapp group "Tentang Anak"; the topic of conversation conducted in whatsapp group "Tentang Anak"; and communication barriers that occur during the health communication process. This study uses a qualitative approach with virtual ethnographic methods. The results of the study showed that the ongoing health communication process included the search by the mother for the health information about their children in whatsapp group "Tentang Anak". The topic of discussion is about information of healthy lifestyles for children, child development, child care, and child healing techniques when experiencing any pain. The communication barriers in the health communication process are personal obstacles, educational barriers, and time constraints.
\end{abstract}

Keywords: health communication process, mother, virtual ethnography.

DOI: https://doi.org/10.29313/mediator.v12i2.4654 


\section{PENDAHULUAN}

Kajian komunikasi kesehatan dalam media sosial menjadi isu yang semakin menarik di era digital ini. Penulis merujuk pada salah satu penelitian kajian komunikasi kesehatan yang dilakukan di Amerika Serikat (AS). Sekitar 69\% orang dewasa AS melaporkan memiliki akses ke internepada 2007. Di antara pengguna internet, 5\% berpartisipasi dalam kelompok dukungan online, 7\% melaporkan blogging, dan 23\% menggunakan situs jejaring sosial (Chou, Hunt, Moser, Richard, Beckjord, Hesse, 2009).

Secara umum, media sosial menembus populasi AS yang independen dari pendidikan, ras/etnis, atau akses kesehatan. Pertumbuhan media sosial saat ini tidak terdistribusi secara seragam di semua kelompok umur. Oleh karena itu, program komunikasi kesehatan yang memanfaatkan media sosial pertama-tama harus mempertimbangkan usia populasi yang ditargetkan untuk membantu memastikan bahwa pesan mencapai audiens yang dituju. Sementara, perbedaan ras/etnis dan status kesehatan ada dalam akses internet, di antara mereka yang memiliki akses internet, karakteristik ini tidak memengaruhi penggunaan media sosial. Temuan ini menunjukkan bahwa teknologi baru, yang diwakili oleh media sosial, dapat mengubah pola komunikasi di seluruh Amerika Serikat (Chou, Hunt, Moser, Richard; Beckjord; Hesse, 2009).

Penulis juga melihat adanya urgensitas penelitian ini karena proses komunikasi kesehatan dalam media sosial diperbarui secara berkelanjutan dengan mengikuti perkembangan penggunaan media sosial tersebut. Rujukan penelitian lainnya dilakukan Park, Reber, dan Chon (2016), yang menggunakan media sosial Twitter. Penelitian tersebut mengangkat cara organisasi kesehatan besar menggunakan media sosial Twitter dalam menyebarkan informasi kesehatan, membangun hubungan, dan mendorong tindakan untuk meningkatkan kesehatan. Organisasi yang diangkat adalah American Heart Association, American Cancer Society, dan American Diabetes Association. Analisis konten dilakukan pada 1.583 tweet untuk memeriksa penggunaan fitur-fitur interaktif Twitter dari organisasi-organisasi ini dan untuk memahami fungsi dan topik pesan dari tweet mereka. Jumlah retweet dan favorit juga diukur sebagai indikator keterlibatan dan dibandingkan dengan fungsi pesan yang berbeda. Hasilnya mengungkapkan bahwa semua organisasi mem-posting tweet asli paling banyak, tetapi mereka berbeda dalam tingkat menggunakan fungsi retweet dan balasan. Alat interaktif yang paling sering digunakan adalah hashtag dan hyperlink. Mayoritas tweet adalah tentang topik yang berhubungan dengan organisasi, sedangkan tweet yang berhubungan dengan kesehatan pribadi mewakili sebagian kecil sampel. Pengikut cenderung menyukai dan me-retweet pesan berbasis tindakan kesehatan pribadi (Park, H., Reber, B. H., \& Chon, 2016). Kedua penelitian di atas memperlihatkan perbedaan yang signifikan tentang pesan yang dimunculkan dalam proses komunikasi kesehatan dalam media sosial dan media online. Kajian yang pertama lebih menekankan pada variasi penggunaan media online, mulai dari blog sampai beragam media sosial yang berkembang. Nilai orisinalitas yang terdapat dalam penelitian penulis adalah tujuan penelitian yang digali fokus pada data kualitatif, yaitu proses komunikasi kesehatan tentang informasi kesehatan ibu dan anak dalam media sosial whatsapp group.

Alasan lainnya yang menguatkan pentingnya dilakukan penelitian ini adalah data yang ditunjukkan Martin-Biggers, Beluska, dan Quick (2015). Penelitiannya tersebut menggambarkan pesan informasi kesehatan yang digunakan komunikator 
sebagai pakar komunikasi kesehatan. Data yang dihasilkan merupakan data kuantitatif. Martin-Biggers, Beluska, dan Quick (2015) menggambarkan bahwa dalam membuat pesan yang menarik minat konsumen sering kali menjadi tantangan bagi komunikator kesehatan. Pemahaman yang lebih baik tentang teknik editor majalah yang digunakan untuk membuat garis penutup dapat membantu komunikator kesehatan dalam upaya mereka untuk membangkitkan minat komunikan. Tes $t$ yang tidak berpasangan mengungkapkan bahwa ibu dari anak kecil $(\mathrm{N}=77)$ melaporkan bahwa mereka secara signifikan $(\mathrm{p}<05)$ lebih termotivasi untuk membaca artikel majalah pendek yang berhubungan dengan kesehatan ketika sampul depan memiliki kebahagiaan/kegembiraan, unik/istimewa, atau tema cepat/urgensi dan secara signifikan kurang termotivasi untuk membaca ketika garis penutup menggunakan tema kontrol/peningkatan. Temuan studi dapat membantu komunikator kesehatan membuat garis penutup yang lebih baik menarik perhatian pembaca (Biggers, Beluska, Quick, 2015).

Daniel (2009) mengatakan salah satu informannya bahkan merawat kesehatannya sendiri dengan cara browsing dalam satu atau dua situs web kesehatan dalam google. Hal tersebut memengaruhi pencarian informasi kesehatan masyarakat. Bahkan ketika kesehatan masyarakat berusaha untuk berkomunikasi. Pusat Pengendalian dan Pencegahan Penyakit menangani masalah besar dengan meluncurkan portal induk baru untuk kesehatan anak-anak (www. cdc.gov/parents) sementara di masa lalu harus mencari dulu 127 halaman topik secara terpisah. Ada banyak peluang serupa untuk memfasilitasi langkah pertama menuju pencegahan (Daniel, 2009).

Selain penelitian Daniel (2009) di atas, ada nilai kebaruan lainnya yang dimunculkan dalam penelitian penulis, yaitu penelitian dalam media sosial. Berbagai media sosial telah menarik perhatian para peneliti untuk mengkaji fenomena yang terjadi di dalamnya. Penelitian serupa lainnya yang mengkaji fenomena komunikasi dalam media sosial telah dilakukan oleh Setiawan (2017) tentang fenomena sosial makna hijrah bagi kalangan anak muda dalam akun media sosial akun LINE Dakwah Islam. Maka, fitur timeLINE sebagai wadah untuk berbagi status, pesan suara, video, foto, kontak, dan informasi lokasi. Fitur tersebut juga digunakan oleh beberapa akun untuk berdakwah. Fenomena dakwah melalui media sosial terutama di kalangan anak muda menarik peneliti untuk melihat keunikan tersendiri dari mahasiswa Fakultas Ilmu Komunikasi Unisba. Keunikan tersebut yaitu adanya anak muda yang berusaha istiqamah dalam proses berhijrah yang tetap terlihat fleksibel dan tetap "melek" teknologi, namun tetap melakukan tollabul ilmi (mencari ilmu) khususnya ilmu agama, tetap mengikuti perkembangan teknologi dalam akun LINE Dakwah Islam. Bagi mereka, hal tersebut menjadi dasar awal rasa ingin tahu dan mengamalkan gaya hidup islami melalui hijrah (Setiawan, Erik; Desiana, Fauzi I; Wulandari, Widi; Salsabila, 2017).

Beberapa penelitian terdahulu di atas merupakan alasan yang menguatkan penulis melakukan penelitian ini. Selain nilai kebaruan yang ada dalam penelitian penulis, tentang adanya proses komunikasi kesehatan yang terjadi dalam media sosial, penulis juga membuktikan adanya urgensitas pentingnya penelitian ini dilakukan. Apalagi mengingat bahwa saaat ini adalah era digital, para ibu pun dapat mengakses segala informasi kesehatan secara digital. Oleh karena itu, perlu dilakukan penelitian tentang proses komunikasi kesehatan yang dilakukan 
Ditha Prasanti, dkk. Analisis Etnografi Virtual Tentang Proses Komunikasi...

oleh sebuah komunitas, bernama "Tentang Anak". Artikel ini merupakan hasil penelitian yang mengungkapkan tentang proses komunikasi kesehatan ibu dan anak dalam media sosial Whatsapp Group "Tentang Anak". Grup "Tentang Anak"merupakan komunitas para ibu yang peduli tentang informasi aktual mengenai kesehatan anaknya.

Berawal dari ketertarikan penulis mengenai para ibu yang sekaligus merupakan perempuan urban serta mengedepankan konsep literasi kesehatan tentang perawatan, penyembuhan, serta kondisi kesehatan anaknya, jika anaknya mengalami sakit. Kegiatan ini merupakan salah satu proses yang erat kaitannya dengan komunikasi kesehatan. Tujuan penelitian ini adalah ingin mendeskripsikan tentang proses komunikasi kesehatan yang terjadi dalam whatsapp group "Tentang Anak" tersebut; topik pembicaraan yang dilakukan dalam whatsapp group "Tentang Anak" tersebut; serta hambatan komunikasi yang terjadi selama proses komunikasi kesehatan dilakukan. Penelitian ini menggunakan pendekatan kualitatif dengan metode etnografi virtual.

\section{METODE}

Dalam penelitian ini, penulis menggunakan pendekatan kualitatif dengan metode etnografi virtual. Metode etnografi virtual adalah metodeyang cocok digunakan karena penulis mengangkat sebuah komunitas virtual dalam media sosial whatsapp group, bernama “Tentang Anak". Christine Hine (2001) mendeskripsikan etnografi virtual yang terdiri atas beberapa prinsip, yaitu : (1). Etnografi virtual mempertanyakan asumsi yang sudah berlaku secara umum tentang internet (Hine, 2000). Dalam penelitian ini, penulis menginterpretasikan internet sebagai medium yang digunakan untuk proses berkomunikasi. (2). Berbeda dengan kehidupan nyata dan fenomena yang muncul dari interaksi face-toface, internet merupakan lapangan yang sangat kompleks dan relasi yang terjadi berdasarkan pada konteks yang digunakan termasuk penggunaan teknologi(Hine, 2000). Dalam hal ini, penulis melihat interaksi antaranggota grup "Tentang Anak" dalam media sosial Whatsapp group tersebut. (3). Internet mengubah pemahaman tentang 'lokasi' penelitian (Hine, 2000). Penulis mengamati penggunaan media sosial whatsapp group "Tentang Anak" yang mewadahi proses komunikasi antaranggotanya di grup tersebut. Grup ini terbentuk sejak 2015 yang lalu, dan masih eksis sampai saat ini. Subjek penelitian penulis dalam hal ini adalah anggota yang tergabung dalam whatsapp group "Tentang Anak", terdiri dari admin dan anggota aktif yang memantau proses komunikasi dalam group tersebut.

\section{TEMUAN DAN DISKUSI}

Hasil penelitian menunjukkan bahwa proses komunikasi kesehatan yang berlangsung meliputi pencarian informasi kesehatan para ibu tersebut tentang kesehatan anaknya dalam whatsapp group "Tentang Anak". Topik pembicaraan yang dilakukan seputar informasi pola hidup sehat bagi anak; tumbuh kembang anak, perawatan anak, dan teknik penyembuhan anak apabila mengalami sakit apapun. Hambatan komunikasi yang ada dalam proses komunikasi kesehatan tersebut adalah hambatan personal, hambatan pendidikan, dan hambatan waktu.

Pertanyaan dan permohonan dukungan paling jelas terpusat pada masalah makan dan tidur. Para ibu menyatakan keprihatinan tentang kapan dan bagaimana anak-anak mereka harus mulai tidur dan makan secara mandiri. Selain tema khusus untuk domain tertentu, tema lintas domain diidentifikas imelibatkan stress pengasuhan ibu, pertanyaan saran dari keluarga / dokter 
anak dan kekhawatiran bahwa anak-anak tidak berkembang secara normal (Porter \& Ispa, 2013).

Forum online telah menjadi ruang para ibu dapat secara terbuka menggambarkan emosi negatif mereka sendiri terhadap pengasuhan dan mengajukan pertanyaan atau mendapatkan kepastian untuk menyelesaikan pesan campuran tentang cara seseorang harus membesarkan bayi dan balita (Porter \& Ispa, 2013).

Merujuk pada data di atas yang mengungkapkan para ibu dapat menceritakan secara terbuka tentang informasi kesehatan dalam forum online pada 2013, penulis melihat bahwa fenomena tersebut terjadi saat ini di Indonesia, salah satunya adalah komunitas para ibu yang menjadi subjek penelitian penulis. Dalam bagian ini, penulis mendeskripsikan hasil penelitian tentang proses komunikasi kesehatan yang terjadi dalam sebuah whatsapp group "Tentang Anak". Informan pertama penelitian, RN, menyampaikan dalam proses wawancara yang dilakukan tentang asal muasal dibentuknya komunitas Tentang anak tersebut. Berikut penuturannya.

"We called him om mod, as the admin of TA. Dia penulis buku tentang anak, terus ngadain komunitas ini buat wadah emak-emak saling sharing or tanya-tanya info yang ada kaitannya sama anak dan seputar kehidupan emak, tapi ya tentu fokusnya ya tentang kesehatan ibu dan anak."

Dalam pernyataannya tersebut, penulis melihat bahwa latar belakang dibentuknya komunitas ini, fokus pada tujuan utamanya adalah sebagai wadah literasi informasi tentang kesehatan ibu dan anak. Pendiri komunitas ini pun merupakan penulis buku tentang anak, yang memiliki peminatan pada bidang anak. RN pun menambahkan hasil wawancaranya sebagai berikut.

"Kalau info seputar anak, sharing info apa pun yang berhubungan dengan anak, tapi ya lebih fokus ke informasi kesehatannya ya, misalnya tumbuh kembang anak, pola hidup sehat, anakanak di sekolah, walaupun kadang bisa jadi curhat kayak personal life ya, hehe.. tapi sejauh ini ya kami memang concern pokoknya ya kesehatan ibu dan anak aja."

Pada bagian kutipan di atas, RN juga menegaskan bahwa topik yang dibicarakan dalam komunitas whatsapp group "Tentang Anak" tersebut fokus pada kesehatan ibu dan anak. Para ibu berbagi tentang aktivitas anakanaknya, mulai dari tumbuh kembang anak, pola hidup sehat, bahkan sampai kegiatan anak di sekolah. Hal ini ternyata dilakukan dalam group tersebut, sematamata sebagai berbagi informasi mengenai anak-anaknya.

"Kalau yang namanya masalah, ada aja terjadi. Hal yang paling sering tuh ya perdebatanya, ada aja emak-emak yang suka frontal gitu negur ke emak lainnya, jadi bikin ribut di group kan. Kalau udah rame gitu, ujungnya ada yang ngerasa terintimidasi. Pada akhirnya, emakemak yang terpojok itu yang jadi korban. Admin group suka sigap deh, jadinya "bersih-bersih member".

Tetapi di balik hal positif tersebut, RN juga bercerita bahwa ada konflik yang tetap terjadi dalam komunitas whatsapp group tersebut. Tentang anak sebagai komunitas online dalam media sosial whatsapp group, tidak lepas juga dari berbagai masalah yang dihadapinya antaranggota grup tersebut. RN menceritakan ketika beberapa orang dalam komunitas grup tersebut ada yang secara frontal berpendapat, sehingga menyudutkan anggota lainnya, lalu membuat anggota lain pun menjadi merasa terintimidasi dalam group tersebut. Konflik ini seringkali terjadi, pada akhirnya admin gruplah yang mengambil alih solusi untuk menyelesaikan masalah tersebut. 
Ditha Prasanti, dkk. Analisis Etnografi Virtual Tentang Proses Komunikasi...

TABEL 1. Topik Pembicaraan Group "Tentang Anak"

(Sumber: Hasil Penelitian, 2018)

\begin{tabular}{lcl}
\hline No & $\begin{array}{c}\text { Pembicaraan Antaranggota Grup } \\
\text { "Tentang Anak" }\end{array}$ & \multicolumn{1}{c}{ Pernyataan Informan } \\
\hline 1 & Tumbuh Kembang anak & $R N$ : "sharing info apapun yang berhubungan \\
& & dengan anak, tapi ya lebih fokus ke informasi \\
& kesehatannya ya, misalnya tumbuh kembang anak, \\
& pola hidup sehat, anak-anak di sekolah, walaupun \\
& kadang bisa jadi curhat kayak personal life ya, \\
& hehe. Tapi sejauh ini ya kami memang concern \\
& pokokna ya kesehatan ibu dan anak aja."
\end{tabular}

2 Perawatan anak

RN: "perawatan anak sih lebih pada berbagi cerita tentang cara ibu-ibu dalam merawat anakanaknya".

3 Pola hidup sehat anak

4 Teknik penyembuhan anak
$\mathrm{RN}$ : “iya pola hidup sehat juga termasuk salah satu yang dibahas dalam grup".

$\mathrm{RN}$ : "trus kalo ada yang anaknya sakit, suka nanya di grup deh, nanti ada ibu-ibu lain yang bakal jawab, sharing pengalamannya, pas anaknya gatal-gatal misalnya, atau lagi gak nafsu makan, langkah apa yang dilakukan, pokoknya seputar teknik penyembuhan anak".
Langkah solutif yang dilakukan admin group adalah dengan cara "bersih-bersih member". RN menjelaskan cara tersebut berarti admin grup akan mengeluarkan anggota yang menimbulkan masalah tersebut terjadi.

Dalam TABEL 1, penulis menggambarkan hasil penelitian tentang topik pembicaraan yang biasa dilakukan oleh anggota grup "Tentang Anak" tersebut.

Temuan lainnya dalam penelitian penulis adalah tentang hambatan komunikasi yang terjadi selama proses komunikasi berlangsung melalui grup "Tentang Anak" tersebut. Hambatan komunikasi yang ada dalam proses komunikasi kesehatan tersebut adalah hambatan personal; hambatan pendidikan; dan hambatan waktu.

Oleh karena itu, dalam bagian ini, penulis mengungkapkan hambatan yang terjadidalam proses komunikasikesehatan di dalam grup "Tentang Anak". Betapa pentingnya mengetahui data tentang hambatan komunikasi, juga penulis temukan dalam beberapa penelitian lain tentang kajian komunikasi kesehatan. Misalnya saja, penulis menemukan pentingnya hambatan pencarian informasi kesehatan dalam penelitian yang diungkapkan oleh Lee \& Chae (2013) tentang Imigran Asia di AS jauh lebih kecil kemungkinannya untuk memiliki asuransi kesehatan atau menggunakan layanan perawatan kesehatan daripada orang Asia kelahiran AS dan orang kulit putih non-hispanik. Selain itu, imigran Asia yang mengakses sistem perawatan kesehatan AS lebih kecil kemungkinannya daripada orang kulit putih non-Hispanik untuk menerima layanan berkualitas 
tinggi. Artikel tersebut mengulas empat hambatan yang dihadapi oleh imigran Asia untuk berpartisipasi dalam sistem perawatan kesehatan AS sepenuhnya: (1) ketidaksesuaian linguistik antara penyedia dan pasien; (2) kepercayaan terkait kesehatan dan ketidakmampuan budaya sistem kesehatan; (3) masalah yang berkaitan dengan mengakses layanan kesehatan; dan (4) diskriminasi dalam sistem perawatan kesehatan. Intervensi untuk meningkatkan kesehatan imigran Asia harus mengatasi hambatan yang dialami di berbagai tingkatan, termasuk yang terjadi secara interpersonal dan institusional, serta faktor sosial yang lebih luas yang memengaruhi akses dan kualitas layanan kesehatan (Clough, J., Lee, S., \& Chae, 2013).

Data lainnya yang menunjukkan pentingnya hambatan komunikasi diungkapkan dalam proses pencarian informasi kesehatan adalah penelitian yang dilakukan oleh Antheunis, Tates, Niebor (2013). Mereka mengungkapkan pasien dan tenaga profesional kesehatan tentang(a) motif dan penggunaan media sosial untuk alasan yang berhubungan dengan kesehatan, dan (b) hambatan dan harapan untuk penggunaan media sosial terkait kesehatan.Mereka melakukan survei online deskriptif di antara 139 pasien dan 153 profesional perawatan kesehatan di bidang kebidanan dan ginekologi. Dalam survei ini, ditanyakan kepada responden tentang motif mereka dan penggunaan situs jejaring sosial (SNS: Facebook dan Hyves), Twitter, LinkedIn, dan YouTube. Hasil menunjukkan bahwa pasien terutama menggunakan Twitter $(59,9 \%)$, terutama untuk meningkatkan pengetahuan dan saran pertukaran dan Facebook (52,3\%), terutama untuk dukungan sosial dan saran pertukaran. Profesional terutama menggunakan LinkedIn (70,7\%) dan Twitter (51,2\%), untuk komunikasi dengan kolega mereka dan alasan pemasaran. Hambatan utama pasien untuk penggunaan media sosial adalah masalah privasi dan tidak dapat diandalkannya informasi tersebut. Hambatan utama profesional adalah ketidakefisienan dan kurangnya keterampilan. Baik pasien maupun tenaga professional kesehatan mengharapkan penggunaan media sosial di masa depan, asalkan mereka dapat memilih waktu penggunaan media sosial mereka (Antheunis, M.L, Tates, K., \& Nieboer, 2013).

Di sisi lain, selain hambatan komunikasi yang dikaji, penulis juga melihat proses komunikasi kesehatan yang berlangsung dalam media online ini pun telah terjadi pada 2002 yang silam. Salah satu penelitiannya yang diungkapkan Bernhardt, Lariscy, Silk, \&Felter (2002) mengatakan internet telah muncul sebagai sarana potensial untuk mendistribusikan komunikasi kesehatan kepada jutaan orang karena bersifat interaktif, dikendalikan oleh pengguna, dan menawarkan luas dan dalamnya informasi. Namun, penggunaannya secara luas oleh publik mungkin terbatas karena tiga masalah utama: privasi dan kerahasiaan, akurasi informasi dan persepsi kredibilitas, termasuk kredibilitas terbatas dari beberapa situs web yang disponsori pemerintah. Untuk mengeksplorasi potensi penggunaan Internet, terutama untuk menyampaikan informasi tentang komunikasi genetika manusia, 15 kelompok fokus dan satu wawancara dilakukan dengan pria dan wanita dewasa Afrika-Amerika dan Eropa-Amerika di kota tenggara. Peneliti menemukan bahwa para peserta mengenali potensi besar di Internet untuk komunikasi kesehatan pada individu( Lariscy, Parrott, Silk, \& Felter, 2002).

Data di atas menguatkan hasil penelitian penulis tentang terdapatnya hambatan dalam proses komunikasi kesehatan yang dilakukan antaranggota dalam whatsapp group "Tentang Anak". 
Ditha Prasanti, dkk. Analisis Etnografi Virtual Tentang Proses Komunikasi...

Hambatan tersebut terdiri atas personal, waktu, dan pendidikan. Hambatan personal ini meliputi faktor yang muncul dari dalam diri anggota grup "Tentang Anak", seperti halnya perbedaan persepsi antaranggota dalam grup tersebut. Misalnya, ketika RN menceritakan konflik yang terjadi antaranggota, ada perbedaan persepsi yang muncul antaranggota dalam grup tersebut. Ketika ada anggota yang menegur anggota lainnya secara terang-terangan, frontal, dan pernyataan yang menyinggung anggota lainnya. Hal tersebut kerapkalI terjadi, sehingga faktor personal tersebut pun menjadi hambatan dalam proses komunikasi yang terjalin antara para anggota lainnya.

Hambatan lainnya adalah pendidikan. Hal ini pun bisa menjadi faktor yang menghambat proses komunikasi yang berlangsung dalam grup tersebut. Perbedaan pendidikan antaranggota grup dapat membuat tingkat pemahaman para anggota pun menjadi berbeda. Misalnya, ada anggota yang memiliki pendidikan berlatar belakang kedokteran, sosial, hukum, ada juga anggota yang memiliki pendidikan pada level sekolah menengah ke atas, dan lain-lain. Keberagaman latar belakang pendidikan tersebut menjadi hal yang dapat menghambat berjalannya proses komunikasi antaranggota secara efektif dalam grup tersebut.Hambatan pendidikan juga terlihat ketika ada anggota yang tidak dapat memahami bahasa ilmiah atau konten topik diskusi yang dibicarakan dalam grup tersebut. Jika ada anggota yang berlatar belakang pendidikan dari kesehatan, maka akan dengan mudah dapat memahami topik diskusi, begitu pun sebaliknya.

Hambatan selanjutnya adalah masalah waktu. RN juga menceritakan konteks waktu dalam hal ini berkaitan dengan perbedaan waktu yang dialami oleh para anggota. Misalnya, ketika ada

TABEL 2. Tahapan Proses Komunikasi Kesehatan Ibu dan Anak dalam Group "Tentang Anak" (Sumber: Hasil Penelitian, 2018)

\begin{tabular}{|c|c|c|c|}
\hline No & Deskripsi & Tahapan & Hambatan \\
\hline 1. & $\begin{array}{l}\text { Pemilihan topik informasi kesehatan yang } \\
\text { disampaikan dalam grup }\end{array}$ & $\begin{array}{c}\text { Tahap Pencarian } \\
\text { Informasi Kese- } \\
\text { hatan }\end{array}$ & $\begin{array}{l}\text { Personal, pen- } \\
\text { didikan, dan } \\
\text { waktu }\end{array}$ \\
\hline 2. & $\begin{array}{l}\text { Proses diskusi yang berlangsung antaranggota dalam } \\
\text { grup }\end{array}$ & $\begin{array}{l}\text { Tahap Pencarian } \\
\text { Informasi Kese- } \\
\quad \text { hatan }\end{array}$ & $\begin{array}{l}\text { Personal, pen- } \\
\text { didikan, dan } \\
\text { waktu }\end{array}$ \\
\hline 3. & $\begin{array}{l}\text { Penyaringan/selektif dalam mengambil informasi } \\
\text { kesehatan yang ada dalam dalam grup }\end{array}$ & $\begin{array}{l}\text { Tahap Penyar- } \\
\text { ingan Informasi } \\
\text { Kesehatan }\end{array}$ & $\begin{array}{l}\text { Personal, pen- } \\
\text { didikan, dan } \\
\text { waktu }\end{array}$ \\
\hline 4. & $\begin{array}{l}\text { Pemilihan peserta komunikasi, jika komunikator yang } \\
\text { berpendapat dalam grup adalah dokter atau berasal } \\
\text { dari medis akan diikuti }\end{array}$ & $\begin{array}{l}\text { Tahap Pemili- } \\
\text { hanSumber yang } \\
\text { kredibel dalam } \\
\text { penyampaian in- } \\
\text { formasi kesehatan }\end{array}$ & $\begin{array}{l}\text { Personal, pen- } \\
\text { didikan, dan } \\
\text { waktu }\end{array}$ \\
\hline 5. & $\begin{array}{l}\text { Penggunaan informasi kesehatan dalam ruang } \\
\text { pribadi, misalnya ketika anggota grup menerapkan } \\
\text { topik tentang teknik penyembuhan pertama demam } \\
\text { pada anak, dengan cara memberikan makan madu, } \\
\text { sayur sop, dan lainnya }\end{array}$ & $\begin{array}{l}\text { Tahap penerapan } \\
\text { informasi keseha- } \\
\text { tan yang diperoleh }\end{array}$ & $\begin{array}{l}\text { Personal, pen- } \\
\text { didikan, dan } \\
\text { waktu }\end{array}$ \\
\hline
\end{tabular}


anggota yang penting meminta informasi dalam grup, tetapi anggota lainnya baru merespons dalam kurun waktu 10 jam kemudian, tidak spontan saat itu juga. Hal ini pun menjadi hambatan dalam proses komunikasi yang terjadi. Hal lainnya ketika diskusi yang dilakukan dalam grup tersebut mengalami konteks perbedaan waktu antaranggotanya, maka proses komunikasi pun menjadi terhambat, tidak berjalan efektif.

Berdasarkan hasil penelitian tersebut, penulis melihat adanya proses komunikasi yang terjalin antara komunikator dan komunikan dalam grup tersebut, yang mengarah pada tahapan pencarian informasi kesehatan melalui grup "Tentang Anak" tersebut. Jika dirumuskan dalam tahapan proses komunikasi, maka penulis dapat membuat tabel di bawah ini.

Dalam TABEL 2, penulis mendeskripsikan kategorisasi alur tahapan proses komunikasi kesehatan yang berlangsung melalui grup online Whatsapp Group "Tentang Anak". Tahapan tersebut dimulai dari pencarian

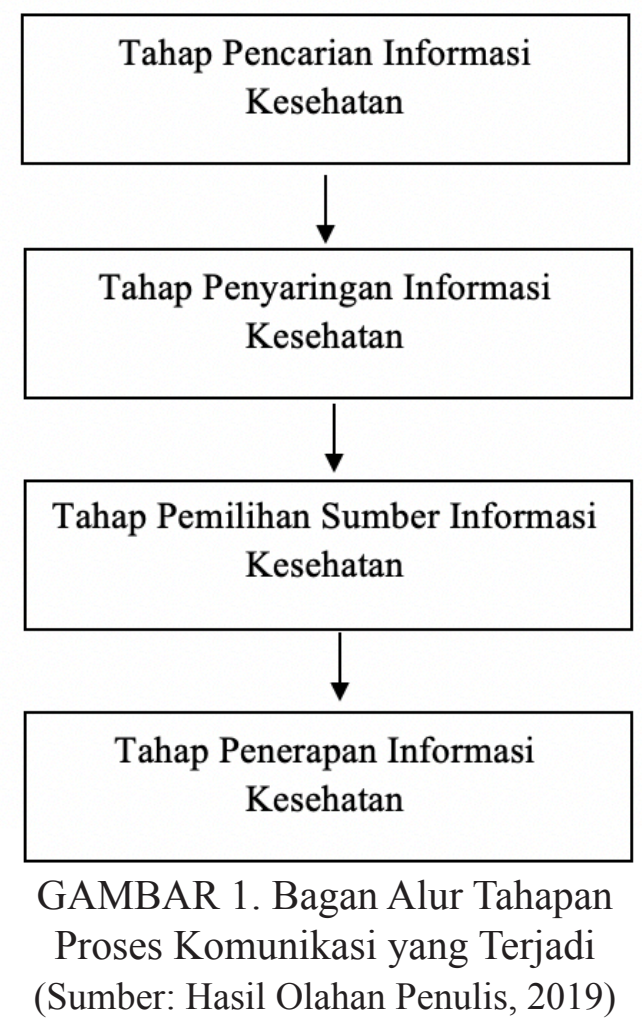

informasi kesehatan, penyaringan informasi kesehatan, pemilihan sumber yang kredibel dalam grup tersebut, dan penerapan informasi kesehatan. Penulis juga mencoba untuk menuangkan tabel di atas dalam bentuk gambar atau bagan hasil penelitian tentang alur tahapan proses komunikasi kesehatan yang terjadi (GAMBAR 1). Tahapan proses komunikasi kesehatan tersebut dimulai dari tahap pencarian informasi kesehatan, lalu masuk ke tahap kedua, yaitu tahap penyaringan informasi kesehatan, setelah itu masuk ke tahap ketiga berikutnya yaitu tahap pemilihan sumber informasi kesehatan. Dalam tahap ini, para anggota grup melakukan pemilihan komunikator. Artinya, siapa yang menyampaikan pesan informasi kesehatan tersebut, dilihat dari kredibilitasnya, sebagai sumber terpercaya, dokter, atau yang lainnya. Selanjutnya, tahap keempat yang dilalui adalah tahap penerapan informasi kesehatan. Dalam tahap tersebut, informan menerapkan informasi yang diperolehnya.

Dalam penelitian ini, penulis tidak melihat proses komunikasi yang berlangsung antara para anggota terjadi sampai pada tahap evaluasi. Hal ini pun menandakan bahwa sumber pencarian informasi kesehatan pun terbatas dalam komunitas whatsapp group "Tentang Anak" tersebut. Selain itu, penulis juga menambahkan analisis hambatan yang dapat terjadi dalam proses komunikasi kesehatan. Dalam setiap tahapan proses yang ada, penulis menemukan bahwa hambatan personal, hambatan pendidikan, dan hambatan waktu, memungkinkan menjadi penghambat berjalannya proses komunikasi antaranggota grup "Tentang Anak" tersebut.

Salah satu teori komunikasi yang relevan dapat digunakan dalam penelitian ini, yaitu teori Computer Mediated Communication (CMC theory). Penulis juga melihat adanya implikasi teori CMC 
ini dalam penelitian yang dilakukan oleh Wright tentang informasi yang dibantu media komputer. Media komputer yang dimaksud dalam penelitian penulis ini adalah penggunaan whatsapp group sebagai media sosial yang berarti wadah/ alat/ media berkomunikasi antar anggotanya dalam media online.

Wright dalam penelitiannya mengungkapkan tentang kelompok dukungan yang dimediasi komputer terkait kesehatan ini menghubungkan fitur-fitur kelompok ini dengan teori yang ada dari bidang dukungan sosial dan penelitian komunikasi yang dimediasi komputer. Wright juga membahas kelompok pendukung yang dimediasi komputer sebagai jaringan pengikat yang lemah, berfokus pada cara kelompok pendukung ini memfasilitasi kesamaan peserta dan dukungan empatik dan mengidentifikasi perubahan dalam komunikasi pendukung karena karakteristik media (Wright, K. B., \& Bell, 2003)

Teori computer mediated communication (CMC) dalam berbagai bentuk, menjadi bagian integral dari inisiasi, pengembangan, dan pemeliharaan dalam hubungan interpersonal. Dalam teori tersebut, dikatakan bahwa individu yang terlibat dalam pembentukan proses komunikasi dalam hampir setiap hubungan konteks. Dalam teori ini juga dapat terlihat bahwa para individu dapat berpartisipasi dalam percakapan sejumlah besar aktor sosial, dari pesan Twitter dari para ahli tidak pernah bertemu dengan blog satu keluarga dan dari pengiriman pesan ke teman Facebook yang baru kenal. Individu juga mengeksploitasi fitur media ini untuk membuat kesan terbaik mereka dan menarik perhatian (Tong \& Walther, 2011a).

Ada tiga prespektif yang mengkaji tentang teori CMC seperti yang diungkapkan oleh Joseph Walther (2011), sebagai berikut: (1) Impersonal, (2) Interpersonal, (3) Hiperpersonal.
Berdasarkan perspektif tersebut, hiperpersonal merupakan perspektif yang paling relevan dengan penelitian penulis ini, karena perspektif tersebut memandang bahwa komunikasi online memiliki efek bagi komunikatornya yang sedikit bebeda dengan face to face. Ketika berkomunikasi melalui media, maka hal ini menciptakan kebebasan bagi para penggunanya dalam membangun komunikasi. Griffin juga mengungkapkan bahwa dalam proses komunikasi melalui media ini, para pelakunya dapat dengan bebas mengungkapkan perasaannya tanpa rasa malu atau canggung yang dapat dilihat langsung oleh lawan komunikasinya (Griffin, 2003).

Hal ini terlihat dalam hasil penelitian penulis yaitu ketika para anggota grup "Tentang Anak" saling mengirimkan pesan berupa informasi kesehatan dalam media sosial whatsapp tersebut. Isi pesan yang dikirimkan tersebut bisa berisi informasi tentang pengobatan penyakit, pola hidup sehat anak, dan lainnya. Selain itu, para penggunanya juga dapat mengungkapkan perasaan lebih banyak dibandingkan dengan komunikasi tatap muka, ini semua dapat terjadi karena kondisi psikologis setiap komunikator juga dapat mempengaruhi proses interaksi yang sedang berlangsung.

Teori ini relevan dengan penelitian yang diangkat penulis karena penulis menemukan adanya interaksi antar anggota grup "Tentang anak" dalam sebuah wadah yang dimediasi oleh media sosial, yaitu Whatsapp Group. Penulis juga melihat proses komunikasi tersebut melibatkan partisipasi para anggota grupnya dalam percakapan yang bervariasi dari anggota grup yang berlatar belakang berbeda. Dalam hal ini, penulis juga melihat para anggota dapat mengeksploitasi percakapan yang ada melalui pencarian informasi kesehatan yang beragam dilontarkan oleh para anggota grup tersebut. 


\section{SIMPULAN}

Kehadiran media sosial menjadi sasaran objek penelitian yang saat ini sering dikaji oleh para peneliti atau akademisi. Tetapi dalam kajian ini, penulis melakukan penelitian tentang proses komunikasi kesehatan yang terjadi dalam komunitas whatsapp group "Tentang Anak". Berdasarkan hasil penelitian yang telah dilakukan, penulis dapat menggambarkan bahwa proses komunikasi kesehatan yang berlangsung meliputi pencarian informasi kesehatan para ibu tersebut tentang kesehatan anaknya dalam whatsapp group "Tentang Anak". Topik pembicaraan yang dilakukan seputar informasi pola hidup sehat bag anak; tumbuh kembang anak; perawatan anak; teknik penyembuhan anak apabila mengalami sakit apapun. Hambatan komunikasi yang ada dalam proses komunikasi kesehatan tersebut adalah hambatan personal; hambatan pendidikan; dan hambatan waktu.

\section{DAFTAR PUSTAKA}

A. Griffin, E. (2003). A First Look at Communication Theory 5th ed. New York: McGraw-Hill.

Antheunis, M.L, Tates, K., \& Nieboer, T. E. (2013). Patients' and health professionals' use of social media in health care: motives, barriers and expectations. Patient Education and Counseling., 92(3), 426-431.

Bernhardt, J. M., Lariscy, R.A. W., Parrott, R. L., Silk, K. J., \& Felter, E. M. (2002). Perceived barriers to Internetbased health communication on human genetics. Journal of Health Communication, 7(4), 325-340.

Chou, WY; Hunt, YM; Moser. Richard P; EB Beckjord; Hesse, B. W. (2009). Social Media Use in the United States: Implications for Health Communication. Journal of Medical Internet Research, 11(4).

Clough, J., Lee, S., \& Chae, D. H. (2013). Barriers to health care among Asian immigrants in the United States: a traditional review. Journal of Health Care for the Poor and Underserved, 24(1), 384-403.

Daniel, K. L. (2009). The power of mom in communicating health. American Journal of Public Health, 99(12), 2119.

Hine, C. (2000). Virtual Ethnography. London: Sage Publications. London: Sage Publication.

Jennifer Martin-Biggers, Katrina Beluska, Virginia Quick, M. T. \& C. B.-B. (2015). Cover Lines Using Positive, Urgent, Unique Language Entice Moms to Read Health Communications. Journal of Health Communication, 20(7), 766-772.

Park, H., Reber, B. H., \& Chon, M. G. (2016). Tweeting as health communication: health organizations' use of Twitter for health promotion and public engagement. Journal of Health Communication, 21(2), 188-198.

Porter, N., \& Ispa, J. M. (2013). Mothers' online message board questions about parenting infants and toddlers. Journal of Advanced Nursing, 69(3), 559-568.

Setiawan, Erik; Desiana, Fauzi I; Wulandari, Widi; Salsabila, I. (2017). Makna Hijrah pada Mahasiswa Fikom Unisba di Komunitas ('followers') Akun “LINE@DakwahIslam.” Mediator Fikom Unisba, 1(Juni).

Tong \& Walther, J. B. (2011). Just say "No thanks": Romantic rejection in computer-mediated communication. Journal of Social and Personal Relationships, 28, 488-506.

Walther, J. B. (2011). Theories of computermediated communication and interpersonal relations. The handbook of interpersonal communication (Vol. 4, pp. 443-479).

Wright, K. B., \& Bell, S. B. (2003). Healthrelated support groups on the Internet: Linking empirical findings to social support and computer-mediated communication theory. Journal of Health Psychology, 8(1), 39-54., 8(1), 39-54. 